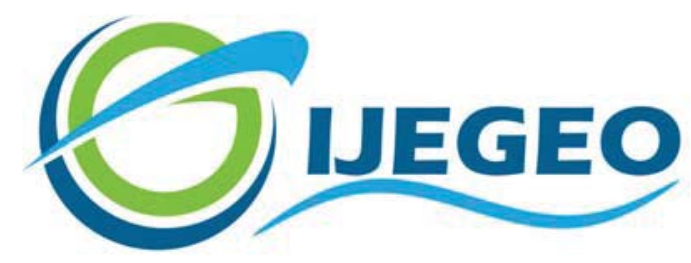

International Journal of Environment and Geoinformatics (IJEGEO) is an international, multidisciplinary, peer reviewed, open access journal.

\title{
New Maritime Trade Routes in the Arctic Region: one of the Strongest Alternative to the Suez Canal
}

\section{İrşad BAYIRHAN and Cem GAZİOĞLU}

\author{
Chief in Editor \\ Prof. Dr. Cem Gazioğlu \\ Co-Editors
}

Prof. Dr. Dursun Zafer Şeker, Prof. Dr. Şinasi Kaya,

Prof. Dr. Ayşegül Tanık and Assist. Prof. Dr. Volkan Demir

Editorial Committee (September 2021)

Assoc. Prof. Dr. Abdullah Aksu (TR), Assit. Prof. Dr. Uğur Algancı (TR), Prof. Dr. Bedri Alpar (TR), Assoc. Prof. Dr. Aslı Aslan (US), Prof. Dr. Levent Bat (TR), Prof. Dr. Paul Bates (UK), İrşad Bayırhan (TR), Prof. Dr. Bülent Bayram (TR), Prof. Dr. Luis M. Botana (ES), Prof. Dr. Nuray Çağlar (TR), Prof. Dr. Sukanta Dash (IN), Dr. Soofia T. Elias (UK), Prof. Dr. A. Evren Erginal (TR), Assoc. Prof. Dr. Cüneyt Erenoğlu (TR), Dr. Dieter Fritsch (DE), Prof. Dr. Çiğdem Göksel (TR), Prof.Dr. Lena Halounova (CZ), Prof. Dr. Manik Kalubarme (IN), Dr. Hakan Kaya (TR), Assist. Prof. Dr. Serkan Kükrer (TR), Assoc. Prof. Dr. Maged Marghany (MY), Prof. Dr. Michael Meadows (ZA), Prof. Dr. Nebiye Musaoğlu (TR), Prof. Dr. Masafumi Nakagawa (JP), Prof. Dr. Hasan Özdemir (TR), Prof. Dr. Chryssy Potsiou (GR), Prof. Dr. Erol Sarı (TR), Prof. Dr. Maria Paradiso (IT), Prof. Dr. Petros Patias (GR), Prof. Dr. Elif Sertel (TR), Prof. Dr. Nüket Sivri (TR), Prof. Dr. Füsun Balık Şanlı (TR), Prof. Dr. Uğur Şanlı (TR), Duygu Ülker (TR), Prof. Dr. Seyfettin Taş (TR), Assoc. Prof. Dr. Ömer Suat Taşkın (TR), Assist. Prof. Dr. Tuba Ünsal (TR), Dr. Manousos Valyrakis (UK), Dr. İnese Varna (LV), Dr. Petra Visser (NL), Prof. Dr. Selma Ünlü (TR), Assoc. Prof. Dr. Oral Yağcı (TR), Prof. Dr. Murat Yakar (TR), Assoc. Prof. Dr. İ. Noyan Yılmaz (AU); Assit. Prof. Dr. Sibel Zeki (TR)

Abstracting and Indexing: TR DIZIN, DOAJ, Index Copernicus, OAJI, Scientific Indexing Services, International Scientific Indexing, Journal Factor, Google Scholar, Ulrich's Periodicals Directory, WorldCat, DRJ, ResearchBib, SOBIAD 


\title{
New Maritime Trade Routes in the Arctic Region: one of the Strongest Alternative to the Suez Canal
}

\author{
İrşad Bayırhan 1,* (D), Cem Gazioğlü ${ }^{1,2}$ (D)
}

${ }^{1}$ Istanbul University, Institute of Marine Sciences and Management, Department of Marine Environment, 34134 Vefa Fatih İstanbul, TR

${ }^{2}$ Istanbul University, Faculty of Architecture, Department of Architecture, 34126 Istanbul TR

* Corresponding author: İ. Bayırhan

Received 06 Apr. 2021

E-mail: ibayirhan@istanbul.edu.tr

How to cite: Bayırhan and Gazioğlu (2021). New Maritime Trade Routes in the Arctic Region: one of the Strongest Alternative to the Suez Canal. International Journal of Environment and Geoinformatics (IJEGEO), 8(3): 397-401. doi. 10.30897/ijegeo.911179

\begin{abstract}
There have been some alternative consequences of global climate change in terms of sea routes. The loss of sea ice in the Arctic has opened up new possibilities for more economical and energy efficient transport. This region has the potential to significantly reduce the distance between the three industrialized areas in the, North America, Europe and East Asia. The fact that the Arctic routes, which are currently facing some obstacles due to environmental and political reasons, will allow regular passage in the future, may be accelerated not only by climate change but also due to heavy traffic on the current Suez Canal Route (SCR). The Suez Canal is one of the most important waterways in the world, providing sea transportation between Asia-Europe-America without the need to travel through Africa. However, over time, the credibility of the Canal in terms of meeting the global supply chain has started to be questioned and alternative solutions have started to be sought. In this study, the importance of Arctic routes, which is a new and alternative route in maritime trade, is emphasized and the preference it will create against SCR is emphasized.
\end{abstract}

Keywords: Arctic Routes, Maritime Trade, NSR, SCR

\section{Introduction}

Oceans, where global climate change impacts can be easily observed, form the basis of almost all commercial and social activities on Earth, while also serving as a means of transporting energy and resources. While global warming affects many aspects of the ocean system, the impact on navigation and transport is of particular importance in predicting the measurable effects of global warming as one of the indirect effects. Since climate change affects the sea, shipping, needs, products and trade, it also deeply affects maritime trade within this whole combination. According to the United Nations Economic Commission for Europe (UNECE, 2013) report, the sector that will be most affected by climate change is maritime transport.

The effects of global climate change are felt in various ways all over the world and have some alternative results. One of these is the new alternative routes emerging in the Arctic region in terms of seaway lines. The surface area of the world's smallest ocean, which now defines its region, is $14,090,000 \mathrm{~km}^{2}$. The Arctic Region has warmed up more than twice as fast as the rest of the Earth, a phenomenon accepted as Arctic amplification (Çetin and Büyüksağnak, 2021; Serreze and Barry, 2011). In the report of the Intergovernmental Panel on Climate Change (IPCC, 2001), it is predicted that the Arctic Ocean, which has been warming by an average of $2.5^{\circ} \mathrm{C}$ since 2000 , will leave the Arctic Ocean completely ice-free by 2035 , especially in the summer months. The loss of sea ice in the Arctic has opened up new opportunities for more economical and energy efficient transport and has increased the feasibility of Arctic shipping. This region has the potential to significantly reduce the distance between the three industrialized areas in the, North America, Europe and East Asia. The minimum sea ice layer of the North Pole, which has been decreasing by an average of $1.2 \%$ each year since 1979 (NSIDC, 2021), enabled the first international transportation in the region on 2009. Today, the total cargo transported from the region exceeds 30 million tons per year (AEC, 2019). The most important shipping lines are oil and LNG from Northwest Russia and Northern Norway to East Asia, iron ore from Russia to China and oil products transported from South Korea to Northern Europe (Çetin, and Köseoğlu, 2020). It can be seen that the tonnage transported over the North Sea is generally liquid and bulk cargoes and the variety of loads is limited. One reason for this is that container shipping, which belongs to liner transport, will be exposed to a wide variety of sea and ice conditions in the Arctic waters. In addition, the high destruction of the ice sheets causes increases the risk of sea ice in maritime trade lines and high ship operating costs if icebreakers are used. However, in the long term, with the further reduction of the Arctic sea ice, container transportation in the region will become more economically viable $(\mathrm{Xu}$ et al., 2018). The fact that the Arctic routes, which are currently facing some obstacles due to environmental and political reasons, will allow regular passage in the 
future, may be accelerated not only by climate change but also due to heavy traffic on the current Suez Canal route.

\section{Brief History of Maritime Trade in the Arctic Region}

Today, the world's largest shipbuilder and major maritime countries are interested in alternative maritime routes in the Arctic that could provide more economy in the future. Although it is assumed that the arctic ice cover has historically been an obstacle to northern transportation, the region has actually witnessed rich maritime activities for centuries since the 11th century (Bennett, 2014). Today, it is also used as a transit route for products to be transported to core markets.

The importance of the Region, which is also included in the historical adventure of Vikings; It took its place in the world geopolitical agenda with the east-west journey of the Venetian explorer John Cabot in 1497 to find a direct route to the East (Ouin, 1875), and in 1525 the Russian diplomat Gerasimov's idea of a waterway connecting the Atlantic and the Pacific (Oktay, 2017). The maritime trade between 16th century Arkhangelsk (Russia), the Middle East (Persian-Arab) and Asia and England led to the formation of commercial ship traffic in the region (Curtin, 1984). The discovery of the Hudson Bay and some eastern coasts of Henry Hudson in 1609 (Ouin, 1875) and the use of the 17th century Mangazeya seaway increased the value of the region to Europeans (Kitagawa, 2008). Vitus Bering in 1728 and James Cook in 1778 entered the Bering Strait from the south (Brigham, 2014). In 1826, Frederick William Beechey reached Point Barrow and explored Alaska's northern coastal borders (McGraw and Walker, 2015). While the effects of John Franklin's expedition, which had an impact on the world public opinion, in 1845 , Robert McClure organized an expedition to the 1850 Northwest Passage (NWP) (Stein, 2015). In 1879, Adolf Erik Nordenskiöld made the first full pass of the Northeast Passage (NEP) from west to east with the ship SS Vega (Handesten, 2020). In 1906, Roald Amundsen successfully completed the NWP passage from Greenland to Alaska (Handesten, 2020). 1932 Professor Otto Yulievich Schmidt was the first person to travel from Arkhangelsk to the Bering Strait without spending the winter on the road with the help of an icebreaker (Kitagawa, 2008). During this period, the first Arctic ports began to be built in the region.

In the 1960s, the USSR began importing wheat from Canada through Churchill Port in the North Pole, and in 1968 Japan and the USSR started line service with a joint cargo ship with Canada (Bennett, 2014). The first commercial cargo ship to pass through the NWP in 1969 was the SS Manhattan (Kitagawa, 2008). In 1974, it was decided to establish the Northern Forum to ensure environmental, climatic, economic and social partnerships of northern countries (Northern Forum, 2020).

In 1987, a total of 6.58 million tons of cargo was transported with 1306 voyages in which 331 ships made on the North Sea Route (NSR) (Liu and Kronbak, 2010). In 1988, the governments of Canada and the USA signed "Arctic Cooperation", an agreement that solved sovereignty problems (Nilsson, 2018). In the 1990s, Japan, South Korea, China, Finland and Italy started negotiations to join the Greater Vladivostok Free Economic Zone (Bennett, 2014). And finally, 1996 Arctic Council was established.

In the 2000s, with the strong summer melts, the NWP and the passages on the NSR increased. In 2005, the NSR was opened to full use. Then, in 2007, the NWP was officially used (Liu and Kronbak, 2010). In 2011, 34 ships passed the entire NSR without any problems. This number reached 46 in 2012 and 71 in 2013 (PAME, 2021). In 2012, the icebreaker Snow Dragon was recorded as the first large ship to use the Transpolar Seaway (TSR) (Blunden, 2012). In 2013, MS Nordic Orion became the first commercial bulk carrier to cross the NWP (Lasserre, 2014). In 2014, the first ship passed the NSR without using an icebreaker. In the same year, it issued the IMO Polar Code.

In 2018, Maersk Line's new "ice-class" container ship, Venta Maersk, had a great impact on its passage through the region. And in 2019, NEP and NWP started seamless transitions at the same time.

\section{New Maritime Trade Routes in the Arctic Region and SCR}

It is possible to examine the traditional routes in world maritime transport in three groups (Stopford, 2008). These three groups and their percentage share from world maritime trade are indicated below;

- $\quad$ The East - West Trades $44 \%$

- North - South Trades $22 \%$

- Intra-regional $34 \%$

SCR is at the focus of the east-west axis of these routes. It also plays a role in north-south trade. It is very important for the import and export of many specific products. The Suez Canal is one of the most important waterways in the world, providing maritime transportation between Asia and Europe without the need to travel around Africa.

However, strong alternatives have recently emerged against the Canal, which is the apple of the eye of traditional routes. Of course, the Ever Given accident, which took place in March 2021 and kept the Canal blocked for days, will take its place in history as a strong reference in explaining the necessity of alternative routes to SCR. It is stated that the damage of the congestion to world trade can reach $\$ 100$ billion (Ha et al., 2021). And it is a fact that the world struggling with the global pandemic crisis will keep the delays in the delivery of medical products in memory for a long time and therefore the prestige of the Canal will be shaken.

One of the alternative routes is the One Belt One Road Project, where the historical Silk Road is invigorated. In 
particular, the land route of the project is the Silk Road Economic Belt; it includes the establishment of railway connections from China to Europe through 6 corridors and the realization of trade-enhancing agreements with the countries of the region ( $\mathrm{Li}$ et al., 2015).

Another alternative route is the new maritime trade routes formed in the Arctic Region. And the number of ships passing and the tonnage transported on these routes are increasing day by day. In addition, the use of Arctic routes is included in the One Belt One Road Project and is called the "Polar Silk Road". Looking at the Arctic Routes in general;

- $\quad$ Northeast Passage (NEP) ○ Northern Sea Route (NSR)

- $\quad$ Northwest Passage (NWP)

- Transpolar Sea Route (TSR)

- Arctic Bridge

NEP is the shipping route to the Pacific Ocean along the Arctic coast of Norway and Russia. NSR is part of NEP. NSR is a shipping route from Novaya Zemlya to Bering Strait. The entire route is in Arctic waters and Russia's EEZ (Exclusive Economic Zone). While the NEP covers the entire Eastern Arctic seas, connecting the Atlantic and Pacific oceans, the NSR does not cover the Barents Sea and does not reach the Atlantic (Stephenson et al., 2014). NWP is the sea route between the Atlantic and Pacific oceans along the Arctic Ocean, the northern coast of North America and the Canadian Arctic Archipelago. The archipelago is separated from each other and from the Canadian mainland by a series of Arctic waterways known as the Northwest Passages (or Northwestern Passages) (Ostreng et al., 2013). The Northwestern Gateway consists of three parts:

\section{- East}

- East of Baffin Island

- West of Baffin Island

- Center: Canadian Arctic Archipelago

o North

○ South

- West

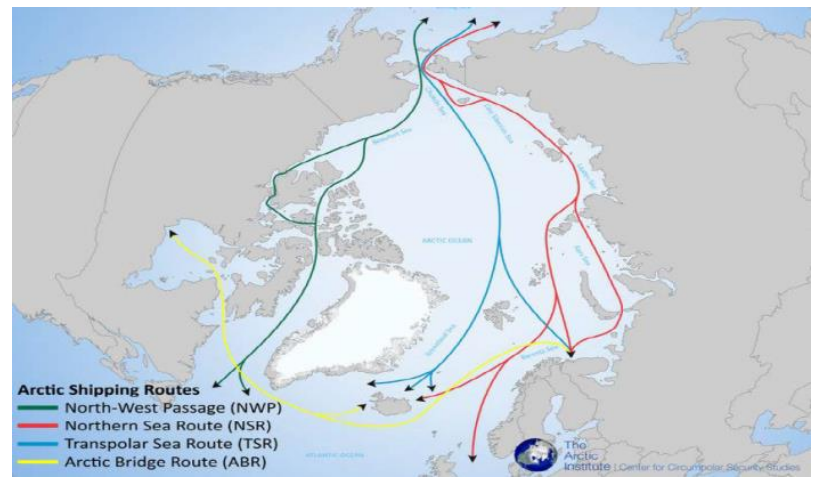

Fig. 1. North Pole Routes (Arctic Institute, 2014)

The Transpolar Sea Route is an Arctic shipping route that runs from the Atlantic Ocean through the center of the Arctic Ocean to the Pacific Ocean. It is also called the Trans-Arctic Route. The TSR passes outside the
EEZs of the Arctic coastal states. The Arctic Bridge or Arctic Sea Bridge is a seasonal sea route of approximately 3,600 NM long connecting Russia to Canada (Kitagawa, 2008; Ostreng et al., 2013). It is possible to see all of the aforementioned routes in Figure 1.

The region remained ice-free many times, especially in September, enabling Arctic maritime transport. In the winter of 2018, ships used the route without icebreakers for the first time. A new record was achieved each year in terms of the number of ships and tonnage compared to the previous year, and the Arctic Economic Council stated that the cargo volumes transported will reach up to 100 million tons by 2025 (AEC, 2019). Especially the infrastructure investments and maritime services made by Russia for the functioning of the NSR route, China's intense interest in the region and the increasing bilateral cooperation in the last 15 years are clearly observed (Bennett, 2014). One of the challenges of turning NSR into a competitive route is that ships often want to stop at multiple ports during a voyage. However, with the further reduction of the arctic sea ice, container shipping in the region will become more economically viable. Because this route significantly shortens the distance between East Asia and Northwest Europe, one of the most important trade areas of the sea route. The NSR is about $40 \%$ shorter for ships sailing from Northern Europe to China (or vice versa) compared to sailing over the Suez Canal and the Strait of Malacca (Bird et al., 2008; Xu et al., 2018). Peters et al. 2011 stated in their research that NSR will be used for approximately $8 \%$ of the total container trade between Asia and Europe in 2030, and approximately $10 \%$ of all container traffic between Asia and Europe in 2050 (Peters et al., 2011).

In the literature, in studies examining the efficiency of northern routes, it is frequently encountered to compare the traditional SCR and the new NSR route of ships traveling between Asia - Europe lines (Lasserre, 2014; Liu and Kronbak, 2010; Omre, 2012; Xu et al., 2018). Because, as the share of the arctic routes from the world maritime transport increases, the Mediterranean trade will be affected at the same rate due to SCR. Suez (Red Sea) is the most important point of the Mediterranean trade axis and it is the gateway for Far East origin cargoes to the Middle East, Russia, North Africa and Europe. For this reason, the impact of the Arctic region transportation, which has been increasing since 2009 , on the number of ships passing over SCR, is being followed with great interest.

\section{Discussion and Conclusion}

Especially during the Pandemic days, the reliability of the Suez Canal Route has been a matter of debate, when the vital consequences of the disruptions in the global supply chain are once again understood. The crisis caused by the extraordinary traffic congestion on the Asia-Europe-America line, especially in the transportation of special products such as medical products and petroleum, has increased the pressure on the maritime industry. The fact that this special mission 
of the Suez Canal, through which roughly one tenth of the world trade passes, must be shared, has come to light. For this reason, it will be inevitable that some new and alternative routes in maritime trade will get a share from SCR.

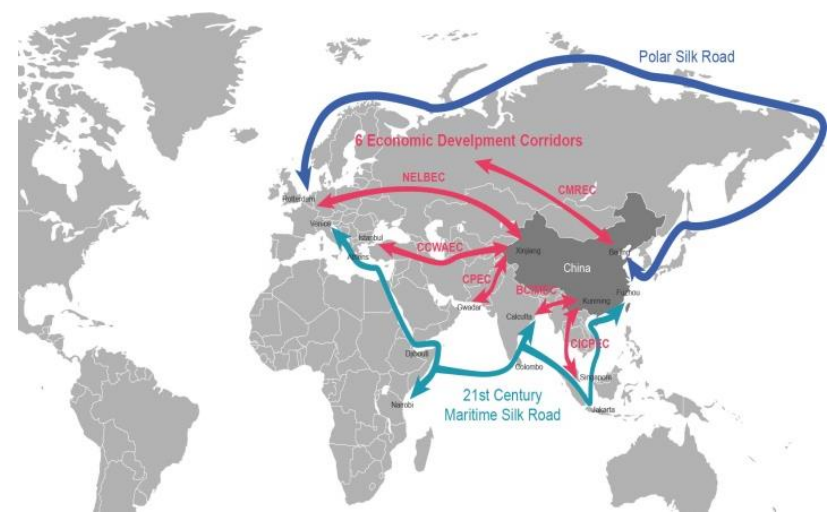

Fig. 2. Belt and Road Initiative Corridors (Ibold, 2018)

One Belt, One Road and Arctic Routes are the two most powerful alternatives that can answer this big problem. Moreover, even the Belt-Road Project involves the use of Arctic Routes in maritime trade (shown in Figure 2). Because climate change has increased seaworthiness in the Arctic Region. And equally, ship operating expenses in the North Pole have begun to gain affordable costs.

The rapidly decreasing amount of ice in the Arctic Region and the feasibility of the Arctic maritime transportation are of critical importance due to the geographical locations of the countries on the route as well as their economic and political positions. In particular, countries such as China, Russia, Japan and South Korea aim to connect to the Atlantic via NSR. In addition, products need to be transported from source regions such as the Arctic to core markets in places such as Asia. For this reason, the region is also very suitable for new collaborations. Infrastructure initiatives are sought for liner ship operations and investment is expected for this organization. In addition; the region is a new economic area that will attract many sectors with high added value for the shipbuilding sector, coastal structures and other construction activities.

It is obvious that the impact of the pandemic effect on maritime trade, the pressure on freight prices, the realization that alternative routes instead of the SCR will shift from temporality to permanence, will be more necessary for regional and global decision makers than preference.

The ice melted by global warming in the northern hemisphere does not only reveal the resources on the sea floor, but also promises alternative routes that will radically affect world trade. The shock wave that occurs when the Suez Canal is temporarily closed makes it easier for the northern route to find its place among the alternatives, but the safety and reliability of the middle route that crosses the whole of Asia will determine the fate of these routes.

\section{References}

AEC. (2019). Arctic Economic Council Maritime Transportation Working Group Report: The State of Maritime Transportation in the Arctic. Arctic Economic Council.

Bennett, M. M. (2014). North by Northeast: toward an Asian-Arctic region. Eurasian Geography and Economics, 55(1), 71-93.

Bird, K. J., Charpentier, R. R., Gautier, D. L., Houseknecht, D. W., Klett, T. R., Pitman, J. K., Moore, T. E., Schenk, C. J., Tennyson, M. E., Wandrey, C. R. (2008). Circum-Arctic resource appraisal: Estimates of undiscovered oil and gas north of the Arctic Circle. US Geological Survey.

Blunden, M. (2012). Geopolitics and the northern sea route. International Affairs, 88(1), 115-129.

Brigham, L. W. (2014). Polar maps: Early eighteenth century vision of a northeast passage. Polar Geography, 37(2), 134-136.

Çetin, O., Büyüksağnak, Y. B. (2021). Turkey’s Interest in the Arctic Region: the Evaluation of being a Party to the Svalbard Treaty. International Journal of Environment and Geoinformatics (IJEGEO), 8(3), 350-358. doi.org/10.30897/ijegeo.887540

Çetin, O., Köseoğlu, M. (2020). A Study on the Classification of Maritime Security Threat Topics, International Journal of Environment and Geoinformatics, 7(3), 365-371. doi. 10.30897 /ijegeo.742336

Curtin, P. D. (1984). Cross-cultural trade in world history (E. Burke (ed.)). Cambridge University Press.

Ha, K. O., Blas, J., Magdy, M., Koh, A. (2021, March 27). How a Desert Wind Blew $\$ 10$ Billion of Global Trade Off Course. Bloomberg.

Handesten, L. (2020). Nordic polar heroes. In G. Hermansson \& J. Jens Lohfert (Eds.), Exploring NORDIC COOL in Literary History (Vol. 15). John Benjamins Publishing Company.

Ibold, S. (2018). Belt and Road Initiative. BRI Projects.

IPCC. (2001). Greenhouse Gas Emission Mitigation Scenarios and Implications. In Metz B. vd (Ed.), Climate Change 2001: Mitigation: Contribution of Working Group III to the Third Assessment Report of the Intergovernmental Panel on Climate Change. Cambridge Uni. Press.

Kitagawa, H. (2008). Arctic routing: Challenges and opportunities. WMU Journal of Maritime Affairs, $7(2), 485-503$.

Lasserre, F. (2014). Case studies of shipping along Arctic routes. Analysis and profitability perspectives for the container sector. Transportation Research Part A: Policy and Practice, 66, 144-161.

Li, P., Qian, H., Howard, K. W. F., Wu, J. (2015). Building a new and sustainable "Silk Road economic belt." Environmental Earth Sciences, 74(10), 7267-7270.

Liu, M., Kronbak, J. (2010). The potential economic viability of using the Northern Sea Route (NSR) as an alternative route between Asia and Europe. Journal of Transport Geography, 18(3), 434-444. 
McGraw, M., Walker, H. J. (2015). Closing the Gap: Exploration and Mapping of the Alaskan Arctic Coast. Focus on Geography, 58(4), 163-172.

Nilsson, A. E. (2018). The United States and the making of an Arctic nation. Polar Record, 54(2), 95-107.

Northern Forum. (2020). History of Northern Forum.

NSIDC. (2021). Sea Ice News and Analysis. National Snow and Ice Data Center.

Oktay, A. (2017). Arctic Policy of the Russian Federation. Avrasya Incelemeleri Dergisi, 6(1), 57-95.

Omre, A. (2012). An economic transport system of the next generation integrating the northern and southern passages. Institutt for marin teknikk.

Ostreng, W., Eger, K. M., Fløistad, B., Jørgensen-Dahl, A., Lothe, L., Mejlænder-Larsen, M., Wergeland, T. (2013). Shipping in Arctic waters: a comparison of the Northeast, Northwest and trans polar passages. Springer Science \& Business Media.

Ouin, W. (1875). The Arctic Expedition. After Work, 2, $170-173$.

PAME. (2021). Northern Sea Route Transits 2011-2015. Arctic Council, Protection of the Arctic Marine Environment. https://pame.is/projects/arcticmarine-shipping/older-projects/northern-sea-routeshipping-statistics

Peters, G. P., Nilssen, T. B., Lindholt, L., Eide, M. S., Glomsrød, S., Eide, L. I., Fuglestvedt, J. S. (2011). Future emissions from shipping and petroleum activities in the Arctic. Atmospheric Chemistry and Physics, 11(11), 5305-5320.

Serreze, M. C., Barry, R. G. (2011). Processes and impacts of Arctic amplification: A research synthesis. Global and Planetary Change, 77(1-2), 85-96.

Stein, G. M. (2015). Discovering the North-West Passage: The four-year Arctic odyssey of HMS Investigator and the McClure expedition. McFarland.

Stephenson, S. R., Brigham, L. W., Smith, L. C. (2014). Marine accessibility along Russia's Northern Sea route. Polar Geography, 37(2), 111-133.

Stopford, M. (2008). Maritime Economics (3rd ed.). Routledge.

UNECE. (2013). United Nations Economic Commission for Europe ECE/TRANS/238, Climate Change Impacts and Adaptation for International Transport Networks, Expert Group Report.

Xu, H., Yang, D., Weng, J. (2018). Economic feasibility of an NSR/SCR-combined container service on the Asia-Europe lane: a new approach dynamically considering sea ice extent. Maritime Policy \& Management, 45(4), 514-529. 